\title{
Assessment of static flood modeling techniques: application to contrasting marshes flooded during Xynthia (western France)
}

\author{
J. F. Breilh ${ }^{1, *}$, E. Chaumillon ${ }^{1}$, X. Bertin ${ }^{1}$, and M. Gravelle ${ }^{1}$ \\ ${ }^{1}$ UMR 7266 LIENSs, CNRS-Université de La Rochelle, La Rochelle, France \\ *Invited contribution by J. F. Breilh, winner of the EGU Outstanding Student Poster (OSP) Awards 2012
}

Correspondence to: J. F. Breilh (jbreil01@univ-lr.fr)

Received: 20 July 2012 - Published in Nat. Hazards Earth Syst. Sci. Discuss.: -

Revised: 20 March 2013 - Accepted: 8 May 2013 - Published: 20 June 2013

\begin{abstract}
This study aims to assess the performance of raster-based flood modeling methods on a wide diversity of coastal marshes. These methods are applied to the flooding associated with the storm Xynthia, which severely hit the western coast of France in February 2010. Static and semi-dynamic methods are assessed using a combination of LiDAR data, post-storm delineation of flooded areas and sea levels originating from both tide gauge measurements and storm surge modeling. Static methods are applied to 27 marshes showing a wide geomorphological diversity. It appears that these methods are suitable for marshes with a small distance between the coastline and the landward boundary of the marsh, which causes these marshes to flood rapidly. On the contrary, these methods overpredict flooded areas for large marshes where the distance between the coastline and the landward boundary of the marsh is large, because the flooding cannot be considered as instantaneous. In this case, semi-dynamic methods based on surge overflowing volume calculations can improve the flooding prediction significantly. This study suggests that static and semi-dynamic flood modeling methods can be attractive and quickly deployed to rapidly produce predictive flood maps of vulnerable areas under certain conditions, particularly for small distances between the coastline and the landward boundary of the low-lying coastal area.
\end{abstract}

\section{Introduction}

Flooding is one of the major natural disasters and affects many regions of the world. Besides causing considerable material damage, this natural hazard leads to the loss of hundreds (sometimes thousands) of human lives every year (Cook and Merwade, 2009). Because of the current sea-level rise and the potential increase in storminess (Schmith et al., 1998) resulting from climate change, extreme coastal flooding events are likely to be more frequent in the future (Brown et al., 2010) while the population in coastal zones is expected to grow (IPCC, 2007). Moreover, anthropogenic effects, such as land reclamation and coastal defense, impact the natural behavior of the coastal zones and the risk of flooding and storm damage (Bates et al., 2005). In this context, it appears fundamental to accurately forecast storm surges and associated coastal floods.

Flooding of coastal lowlands by ocean waters is mainly due to tsunamis (Wächter et al., 2012) and storm-related processes (Benavente et al., 2006) that generate a sea level above the ordinary tide level. Among these processes, the wind effect is often responsible for a large part of the storm surge, particularly in coastal zones bordered by extensive continental shelves and shallow shoreface (Kennedy et al., 2012; Rego and Li, 2009). Thus, low-lying coasts (delta in riverdominated coastal areas, estuaries in tide-dominated coastal areas and lagoons in mixed energy and wave-dominated coastal areas), bordered by large shelves and located on the track of hurricanes and extra-tropical storms, are particularly vulnerable. The Bay of Bengal, which includes extensive deltaic environments, is the region in the world where the deadliest coastal floods resulting from hurricanes have been reported. In 1970, the tropical cyclone Bhola killed more than 300000 people (Das, 1972), and in 2008, the tropical cyclone Nargis killed over 130000 people (Wolf, 2008). Another very vulnerable low-lying coast is the Gulf of Mexico, which includes deltas and lagoons. This vulnerability 
was illustrated by hurricane Katrina in 2005 , which was the sixth-strongest Atlantic hurricane ever reported with the associated flood cost 1500 lives and 84 billion dollars in damages (Blake, 2007). The coastal morphology of northwestern Europe is dominated by estuarine environments (Perillo, 1995), while this region is located on the track of extratropical storms regularly inducing storm surges above one meter (Bertin et al., 2012a; Brown et al., 2010; Nicolle et al., 2009; Wolf, 2008). Low-lying zones of northwestern Europe are thus also vulnerable to coastal flooding. Over the past century, the most serious case took place in the southern North Sea in February 1953. A severe storm induced a threemeters-high surge (Wolf and Flather, 2005) combined with a high spring tide, which caused the flooding of a large part of the Netherlands (Gerritsen, 2005), and to a slighter degree in the UK and Germany. This catastrophe was responsible for 1836 deaths (Gerritsen, 2005; Wolf and Flather, 2005). In the last fifteen years in France, the storms Martin and Xynthia (Bertin et al., 2012a) hit the western coast and caused the flooding of large coastal areas. Xynthia (February 2010) was responsible for 47 deaths and at least 1.2 billion euros in damages in France (Lumbroso and Vinet, 2011). Of these 47 deaths, 41 occurred in the study area.

Beside loss of human lives and material damages, the changes of environmental conditions in coastal habitats associated with marine floods cause a cascade of direct and indirect ecological responses that range from immediate to longterm. For example, inundation of fresh marshes by stormdriven seawater tends to damage or kill all the vegetation, sometimes for several years (Morton and Barras, 2011).

This study is focused on Xynthia and the associated surge because for the first time the flooded areas were accurately mapped in this region of France. Following this storm, a regional storm surge modeling system was developed (Bertin et al., 2012a) and accurate LiDAR (Light Detection and Ranging) data were obtained in order to identify vulnerable coastal areas. Previous topographic data could not be used for such application, because they were not accurate enough to represent coastal defenses and sedimentary barriers. Indeed, LiDAR is able to measure ground elevation with a horizontal resolution $(\sim 1 \mathrm{~m})$ and a vertical accuracy $(\sim 10-15 \mathrm{~cm})$ that are adequate for many flood mapping applications (Gallien et al., 2011). The airborne LiDAR-derived Digital Elevation Models (DEMs) are commonly used to evaluate vulnerability to sea-level rise (Chust et al., 2009, 2010; Webster, 2010; Webster et al., 2006), coastal flood risks (Bernatchez et al., 2011; Webster et al., 2006) and also fluvial flood risks (Cook and Merwade, 2009; Haile and Rientjes, 2005).

This study aims to evaluate the benefits and limitations of a raster-based static method and a semi-dynamic flood modeling method based on high accuracy LiDARderived DEMs. Such methods are commonly used to delineate areas vulnerable to flooding, like the Coastal Flood Risk Prevention Plans (PPR-SM, http://www.risques.gouv.fr/ risques-naturels/inondation) in France, the Flood Insurance
Rate Map (FIRM) from the Federal Emergency Management Agency (FEMA, http://www.fema.gov/) in the USA or flood maps from the UK environment agency (http://www. environment-agency.gov.uk/).

The originality of this study stems from the analysis of a wide diversity of flooded areas, for which the extension of the flooding was accurately delineated. More than 40 separated areas were flooded and mapped, allowing linking the skill of static modeling methods with geomorphological characteristics of flooded areas. The performance of static modeling methods is evaluated against generic morphological parameters, from which this study concludes on the applicability of such methods for other vulnerable coastal environments.

\section{Study area}

\subsection{Geomorphologic setting}

The study area is located along the Atlantic Coast of France, northward of the Gironde Estuary (Fig. 1). The coastline is irregular and characterized by large embayments (locally named "Pertuis Charentais") corresponding to three drown incised-valley (IV) segments (from north to south: the LaySèvre IV, the Charente IV and the Seudre IV (Chaumillon et al., 2008), bounded by the Arvert Peninsula, Ré and Oléron Islands and the south Vendée coastline (Fig. 1). The maximum water depth is $43 \mathrm{~m}$ below the 0 NGF (French vertical datum (Nivellement Général de la France), resulting from mean sea level observations at the Marseille tide gauge between the 2 February 1885 and the 31 December 1896) within the Charente IV and $61 \mathrm{~m}$ within the Lay-Sèvre IV. Nevertheless, because $65 \%$ of the Pertuis Charentais sea floor area is less than $10 \mathrm{~m}$ deep, the marine part of the study area can be considered as shallow.

The landward part of those embayments displays extensive intertidal mudflats that can reach $5 \mathrm{~km}$ width. In the past (from millenaries to centuries) the seaward parts of those onshore incised-valley segments were flooded by the sea (Allard et al., 2008; Billeaud et al., 2004; Chaumillon et al., 2008; Pawlowski, 1998). The rapid siltation and sedimentfill of those IV segments led to the development of extensive coastal marshes, one of them corresponding to the largest coastal marsh of France (the Poitevin Marsh, no. 27, Fig. 1). The natural infilling of those marshes was enhanced by anthropogenic activities, mainly deforestation (Poirier et al., 2011) and land reclamation (Allard et al., 2008; Bertin et al., 2005; Chaumillon et al., 2004).

Those marshes are bounded by rocky outcrops corresponding to the interfluves of the IVs. The elevation of a large part of these marshes is commonly below the highest sea levels reached during spring tides. Considering a coastal area spanning from $10 \mathrm{~km}$ inland to the coastline, between $45 \%$ and $50 \%$ is below the highest astronomical tides (Table 1). To prevent marine flooding, extensive 


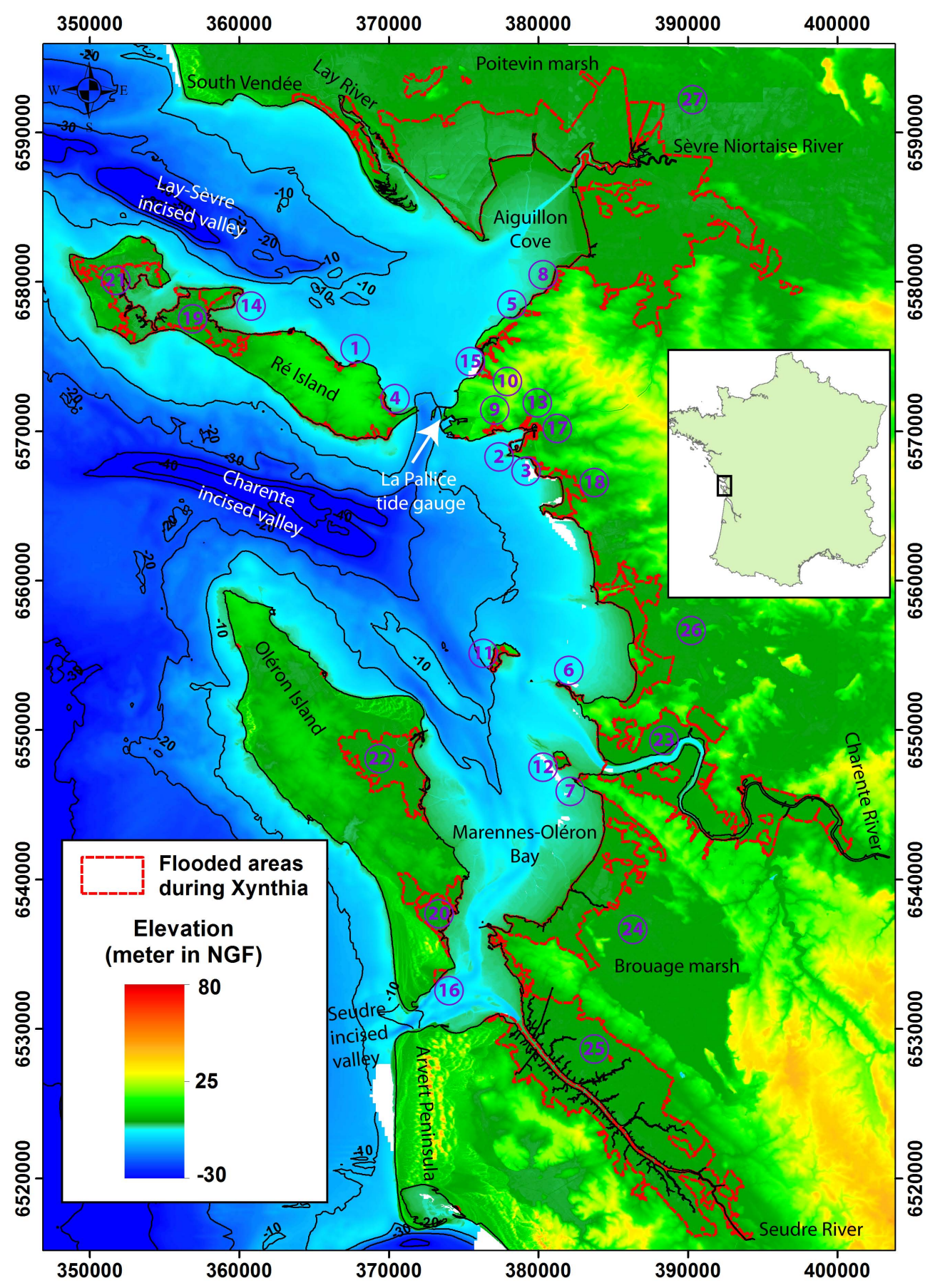

Fig. 1. LiDAR derived Digital Terrain Model (DTM) of the study area. Elevation is shown in meter NGF and the horizontal projection is in meters of Lambert 93 projected coordinate system. Circled numbers 1 to 27 are the studied marshes. The red dotted line shows the extension of the observed flooded areas caused by the Xynthia storm.

dykes, levees (approximately $240 \mathrm{~km}$ ) and locks have been built over the last centuries $(6 \mathrm{~m})$. Due to the construction of all these flood management measurements, wetlands are disconnected from the sea. During high tides, locks are closed, preventing saltwater incursion, and during low tides, locks are opened, allowing the drainage of marshes.

\subsection{Hydrodynamic setting}

The study area is a mixed tide- and wave-dominated system. Tides are semi-diurnal, with amplitude ranging from less than $2 \mathrm{~m}$ (neap tides) to more than $6 \mathrm{~m}$ (spring tides). Mean annual offshore (about $120 \mathrm{~km}$ offshore Oléron Island, 
Table 1. Percentages of the $10 \mathrm{~km}$ band land area (from the present-day coastline to $10 \mathrm{~km}$ inshore) below: (1) the sea level of the mean high water neaps (MHWN); (2) the sea level of the mean high water springs (MHWS); and (3) the sea level of highest astronomical tide (HAT).

\begin{tabular}{lllllllll}
\hline Corresponding tide & \multicolumn{2}{c}{ MHWN } & \multicolumn{2}{c}{ MHWS } & \multicolumn{2}{c}{ HAT } & \multicolumn{2}{c}{ HAT + Storm surge } \\
\hline Water elevation (m NGF) & 1 & 1.5 & 2 & 2.5 & 3 & 3.5 & 4 & 4.5 \\
\hline $\begin{array}{l}\% \text { of below sea level surface area of the } \\
10 \mathrm{~km} \text { wide coastal band }\end{array}$ & $1 \%$ & $3 \%$ & $11 \%$ & $32 \%$ & $45 \%$ & $50 \%$ & $54 \%$ & $56 \%$ \\
\hline
\end{tabular}

Fig. 1) wave conditions are characterized by significant wave heights of $2 \mathrm{~m}$ and peak periods ranging from 8 to $12 \mathrm{~s}$ coming predominantly from the $\mathrm{W}$ to $\mathrm{NW}$, although winter storms can episodically produce waves higher than $9 \mathrm{~m}$ (Bertin et al., 2008).

Four small coastal rivers contribute to moderate freshwater input: the Lay and Sèvre Niortaise rivers that flow into the Pertuis Breton and Aiguillon Cove, and the Charente and Seudre rivers that flow into the Marennes-Oléron Bay (Fig. 1). The analysis of available fluvial discharge data (Banque Hydro, 2012) reveals that fluvial discharges during Xynthia were close to yearly-mean conditions (Table 2), which are too weak to induce any freshwater flood.

\subsection{The Xynthia storm and the associated damages}

Xynthia was a windstorm that hit the coasts of France during the night of the 27th to the 28th of February 2010. The sea-level pressure reached its minimum at 969 mbar. Southern to southwestern winds ranging from 25 to $35 \mathrm{~m} . \mathrm{s}^{-1}$ (hourly mean at $10 \mathrm{~m}$ elevation) blew over the southern part of the Bay of Biscay (Fig. 1) and maximum gusts reaching $45 \mathrm{~m} . \mathrm{s}^{-1}$ were recorded on Ré Island (Fig. 1) (Bertin et al., 2012a). Xynthia generated a storm surge that reached its maximum in the central part of the Bay of Biscay (Bertin et al., 2012a). Storm surges during Xynthia were estimated by comparing the predicted astronomical tide to the measured sea level and this comparison showed that the storm surge in La Pallice harbor exceeded $1.50 \mathrm{~m}$ (Fig. 2). This storm surge was in phase with a high spring tide, causing an extreme water level of $4.5 \mathrm{~m} \mathrm{NGF}$. Considering the work of Simon (2008) on extreme water levels, this value would be associated with a return period larger than $100 \mathrm{yr}$. Many natural barriers and sea-walls were submerged and/or breached, causing the flooding of very large areas (approximately $400 \mathrm{~km}^{2}$ in the study area).

Xynthia was one of the costliest and deadliest storms to ever strike France in modern history. Tourism, farming and aquaculture are three major economic activities of this part of France. Saltwater flooding of farmlands was disastrous to the farming industry, firstly because the saltwater-inundated lands can remain contaminated by salt for several years, rendering them impossible to crop. Secondly, hundreds of cattle were drowned. Many aquaculture infrastructures, located in marshes, as well as tourism infrastructures were destroyed.
In term of loss of life, some were due to urbanized, heavilyinhabited areas also being flooded. Thus, the total number of fatalities directly related to Xynthia exceeded 40 on the western coast of France and the material damages were estimated to be more than 1.2 billion euros.

\subsection{Classification based on geomorphology and exten- sion of flooded areas}

For this study, only the inundated marshes with surface areas larger than $0.05 \mathrm{~km}^{2}$ are considered. The 27 corresponding marshes (Fig. 1) display a huge variety in terms of shapes and surface areas. In order to quantify the surface area of those marshes, the $5 \mathrm{~m}$ NGF isoline is considered the arbitrary landward boundary of the marshes, and the coastline, defined as the maximum landward inundation during highest astronomical tides, is considered as the seaward boundary of the marshes. The marshes are arbitrarily classified according to their size (Fig. 1 and Table 3 ). These parameters allow 3 classes of marshes: small marshes $\left(<30 \mathrm{~km}^{2}\right)$, large marshes $\left(>30 \mathrm{~km}^{2}\right.$ and $\left.<500 \mathrm{~km}^{2}\right)$ and very large marshes $\left(>500 \mathrm{~km}^{2}\right)$.

\section{Data and methods}

\subsection{Sea level during Xynthia}

Sea level measurements during the Xynthia storm at La Pallice tide gauge (Fig. 1) were collected from the REFMAR (www.refmar.shom.fr) database. The maximum sea level reached at this tide gauge during the storm was about $4.5 \mathrm{~m}$ NGF (Fig. 2). In order to investigate the spatial variations of the maximum sea level during the Xynthia storm, a new modeling system was developed and implemented over the northeast Atlantic Ocean. This modeling system realizes the coupling in two horizontal dimensions between the circulation model SELFE (Zhang and Baptista, 2008) and the spectral wave model WaveWatch III (Tolman, 2009). SELFE uses a combination of finite volume and finite element methods to solve the shallow water equations and employs a Lagrangian method to treat the advective terms, which guaranties good stability even when using large time steps. WWIII uses finite differences on regular grids to solve the spectral wave action equation. A detailed description of this modeling system and its application can be found in Bertin et al. (2012a). These 
Table 2. Mean, maximum and daily for the day of Xynthia discharges of the four main rivers of the study area.

\begin{tabular}{lllll}
\hline River & Lay & Sèvre Niortaise & Charente & Seudre \\
\hline Period of measure & $2003-2012$ & $1969-2012$ & $1998-2012$ & $1998-2012$ \\
Mean discharge for all period $\left(\mathrm{m}^{3} \cdot \mathrm{s}^{-1}\right)$ & 12 & 11.6 & 69 & 1.5 \\
Maximum daily discharge $\left(\mathrm{m}^{3} . \mathrm{s}^{-1}\right)$ & 214 & 255 & 1037 & 19 \\
Daily discharge 28.02.2010 $\left(\mathrm{m}^{3} \cdot \mathrm{s}^{-1}\right)$ & 31 & 6.2 & 120 & 1.5 \\
\hline
\end{tabular}

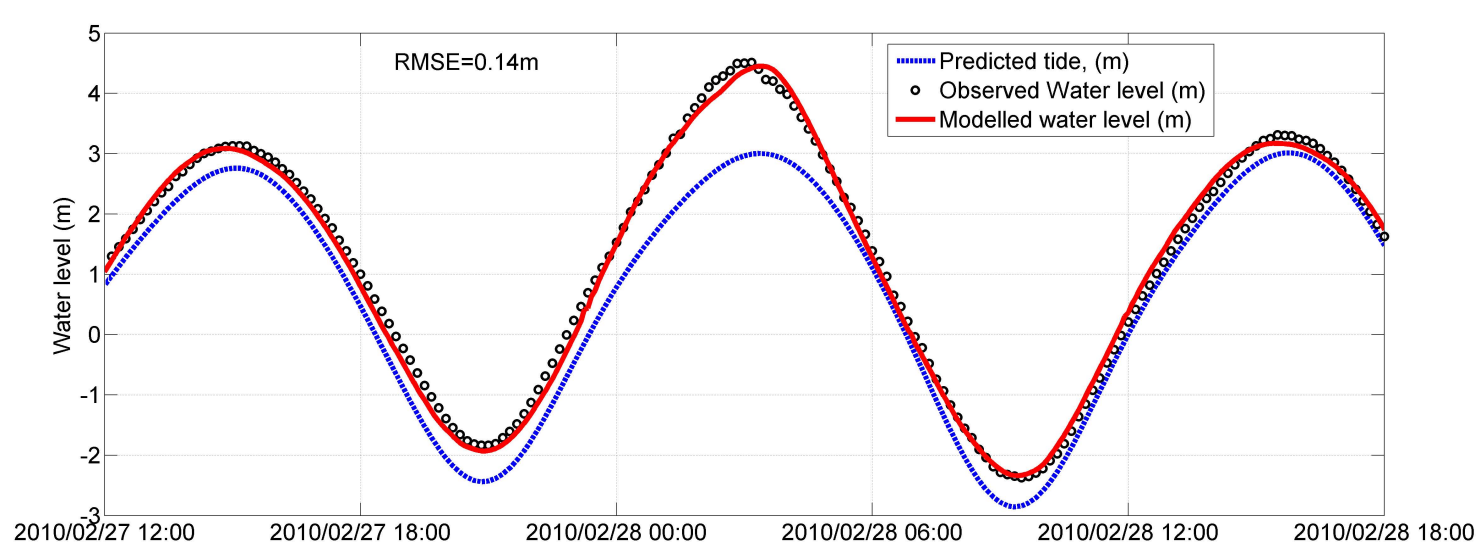

Fig. 2. Predicted tide (blue line), observed water level at the La Pallice tide gauge (black circles) and modeled water level from Bertin et al. (2012a) storm surge modeling system (red line), in meter NGF, during the Xynthia storm.

authors showed that the storm surge associated with Xynthia could only be predicted accurately if the wind stress was computed using a wave-dependent parameterization. This behavior was explained by a particular sea state during Xynthia, characterized by young and steep wind waves, which enhanced the ocean roughness and thereby the wind stress.

From the model results, it appeared that the maximum sea level reached during Xynthia showed significant spatial variations. Maximum sea level varied from $4 \mathrm{~m}$ NGF at the entrances of the Pertuis de Maumusson and Pertuis d'Antioche to almost $5 \mathrm{~m}$ NGF within the Aiguillon Cove (Fig. 3).

\subsection{Topographic and bathymetric datasets}

The high resolution topographic datasets originate from both LiDAR and RTK-GPS (Real-Time Kinematic - Global Positioning System) measurements. LiDAR is a mapping technology that is increasingly used for coastal geomorphologic studies. This technology is appropriate for such analyses since it provides spatially dense and accurate topographic data (Chust et al., 2008; Goff et al., 2009; Haile and Rientjes, 2005; Mazzanti et al., 2009; Poulter and Halpin, 2008; Webster, 2010; Young et al., 2011). The LiDAR is a laser altimeter that measures the range from a platform with a position and altitude determined from GPS and an inertial measurement unit (IMU). Basically, it uses a scanning device that determines the distance from the sensor to a set of ground points roughly perpendicular to the direction of flight (Chust et al., 2008). In 2010, the French National Geographic Institute (IGN) carried out the topographic mapping of the entire coastal area of the Pertuis Charentais four months after Xynthia, using the LiDAR technology. The aerial flights were carried out between low- and mid-tide. A terrestrial DEM was generated from the LiDAR data with a resolution of $1 \mathrm{~m}$ and a vertical accuracy of $0.15 \mathrm{~m}$ (root mean square error, hereafter RMSE) in low vegetated and gently sloping areas. The accuracy was assessed by IGN in test zones, using GPS receivers with RTK system. In this study, a ground (bare-earth, i.e. excluding objects such as buildings, trees, and shrubs) DTM obtained from the DEM was used. In order to better represent some key topographic features such as dykes, levees and seawalls, additional measurements based on RTK-GPS were included. The theoretical vertical accuracy of our devices (Topcon hyperpro) is $0.02 \mathrm{~m}$, but the operational accuracy, which includes uncertainties related to the measurement, would rather be of the order of $0.05 \mathrm{~m}$. This data could locally improve the reliability of the LiDAR DTM, as shown by Gallien et al. (2011).

The bathymetric datasets shown in Fig. 1 is a combination from different sources. The bathymetry of intertidal areas was determined using the LiDAR technology, between lowand mid-tide. For subtidal areas, the bathymetry originates from the SHOM (French Navy Hydrographic and Oceanographic Service) and was measured with echo sounders. In areas where there was a lack of data between the intertidal LiDAR data and the subtidal bathymetry, complementary 
Table 3. The 27 marshes of the study area classified according to size. Surface area of the flooded area during Xynthia and maximum sea level during this storm computed by the Bertin et al. (2012a) storm surge modeling system.

\begin{tabular}{|c|c|c|c|c|}
\hline Marsh no. & Marsh name & $\begin{array}{l}\text { Marsh area } \\
\left(\mathrm{km}^{2}\right)\end{array}$ & $\begin{array}{l}\text { Observed flooded area } \\
\left(\mathrm{km}^{2}\right)\end{array}$ & $\begin{array}{l}\text { Modeled maximum sea } \\
\text { level at the seaward } \\
\text { boundary of the marsh } \\
\text { during Xynthia (m) }\end{array}$ \\
\hline 1 & La Flotte & 0.06 & 0.04 & 4.56 \\
\hline 2 & Port des Minimes & 0.13 & 0.10 & 4.44 \\
\hline 3 & CG17 butte de tir & 0.23 & 0.30 & 4.44 \\
\hline 4 & Rivedoux-Goguette & 0.27 & 0.08 & 4.30 \\
\hline 5 & Golf de la Prée & 0.31 & 0.29 & 4.70 \\
\hline 6 & Fouras & 0.42 & 0.29 & 4.45 \\
\hline 7 & Port des Barques Ouest & 0.42 & 0.17 & 4.46 \\
\hline 8 & Coup de Vague & 0.48 & 0.44 & 4.75 \\
\hline 9 & Port Neuf & 0.50 & 0.34 & 4.43 \\
\hline 10 & Pampin & 0.51 & 0.37 & 4.60 \\
\hline 11 & Aix & 0.52 & 0.46 & 4.43 \\
\hline 12 & Ile Madame & 0.54 & 0.47 & 4.45 \\
\hline 13 & Parc La Rochelle & 1.30 & 0.12 & 4.46 \\
\hline 14 & Loix Est & 1.75 & 1.52 & 4.43 \\
\hline 15 & Port du Plomb & 1.90 & 1.40 & 4.61 \\
\hline 16 & Saint-Trojan & 2.69 & 0.38 & 4.10 \\
\hline 17 & La Rochelle Centre & 5.86 & 0.56 & 4.46 \\
\hline 18 & Aytré-Angoulins & 8.15 & 3.38 & 4.44 \\
\hline 19 & Loix Ouest Couarde & 13.80 & 9.13 & 4.41 \\
\hline 20 & Château d'Oléron & 14.03 & 7.88 & 4.40 \\
\hline 21 & Ré Nord & 21.15 & 10.70 & 4.53 \\
\hline 22 & Boyardville & 64.50 & 16.80 & 4.44 \\
\hline 23 & Charente & 83.00 & 48.25 & 4.46 \\
\hline 24 & Brouage & 120.00 & 28.75 & 4.43 \\
\hline 25 & Seudre Estuary & 125.00 & 88.31 & 4.17 \\
\hline 26 & Chatelaillon-Yves & 160.00 & 14.00 & 4.45 \\
\hline 27 & Poitevin Marsh & 997.00 & 158.21 & 4.75 \\
\hline
\end{tabular}

bathymetric measurements were carried out by our team using a single beam echo sounder mounted with the same RTK-GPS as used for topographic surveys.

\subsection{Observed flooded areas related to the Xynthia storm}

The area flooded by Xynthia in the northern part of the study area, i.e., marsh no. 27, northward of the Sèvre Niortaise Estuary, was determined using flood inundation maps from the SERTIT (regional service of image processing and remote sensing), combining images from SPOT 4 (10 m resolution, taken two days after the storm), ENVISAT ASAR (12.5 m resolution, taken two days after the storm), and RADARSAT 2 (6 $\mathrm{m}$ resolution, taken 4 days after the storm) satellites. For all other flooded areas, field observations were carried out by SOGREAH, a French consulting agency (DDTM-17, 2011). In situ limits of storm deposits, physical marks or markers, and damages to vegetation were observed to determine horizontal and vertical water limits. By compiling all these data in a GIS, the polygons of the inundated areas (Fig. 1) were then obtained. Considering the delay between the storm and the satellite images, it is not possible to assess the polygon extension accuracy for the northern part of the marsh no. 27. Nevertheless, SERTIT inundation maps were compared with SOGREAH field observations for areas where both datasets were available. These comparisons showed a good agreement between the two datasets. Considering this difficulty to accurately assess the horizontal accuracy of maximum water limits, we arbitrarily set it to $10 \mathrm{~m}$ for urbanized flooded areas and $100 \mathrm{~m}$ for marshes without any structures. These polygons were considered as the observed flooded areas for Xynthia and were used to evaluate the simulated flooded areas.

\subsection{Flooding methods}

The following methods are presented according to three levels of increasing complexity: (1) method SM1 is a static flood modeling method that uses the maximum sea level recorded during the storm at La Pallice tide gauge (Fig. 2); (2) method SM2 is a static flood modeling method considering the spacevarying maximum sea levels extracted from the modeling system of Bertin et al. (2012a) (Fig. 3); and (3) method SO 


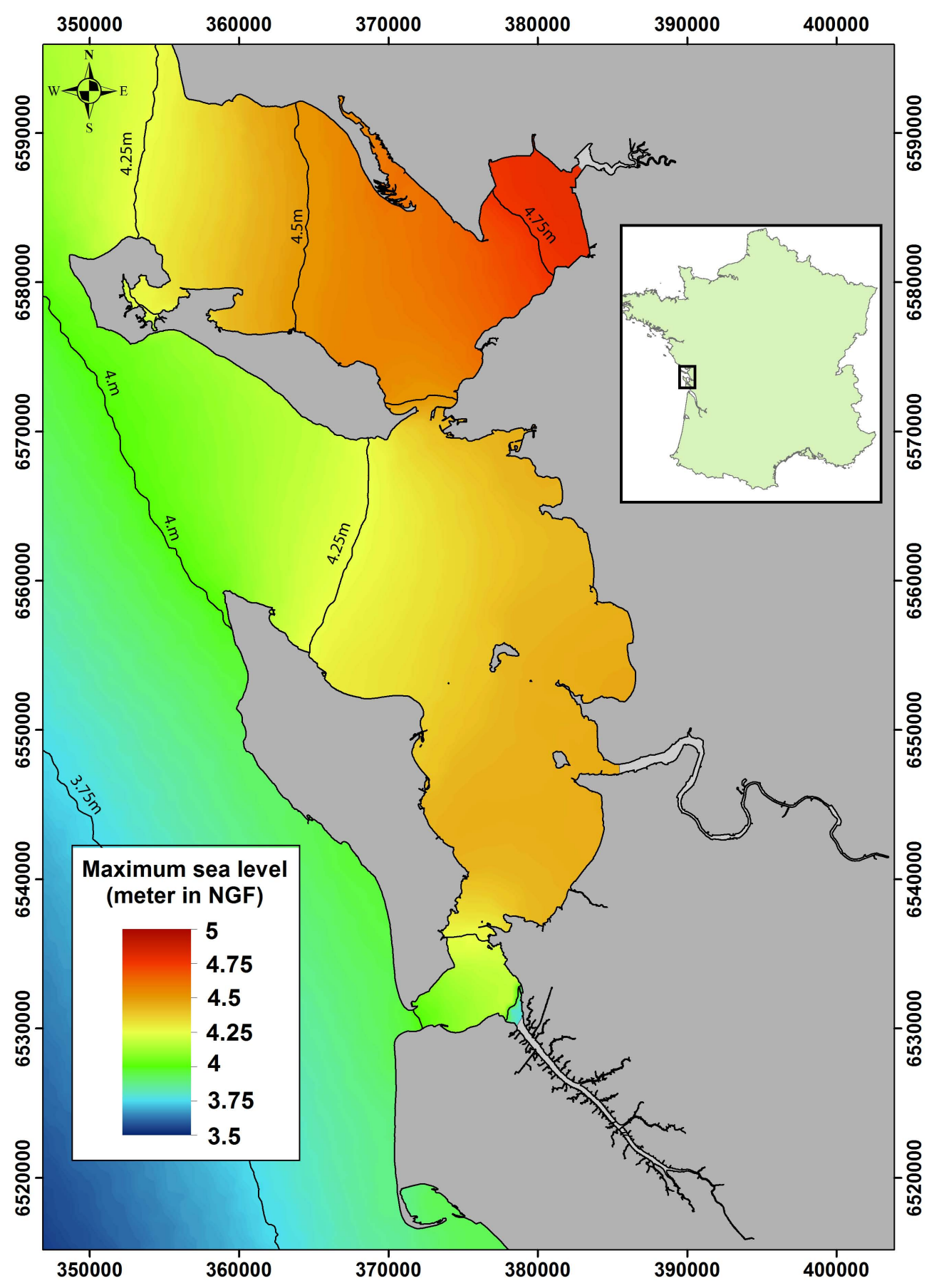

Fig. 3. Maximum sea level during the Xynthia storm in meter NGF calculated from the storm surge numerical model of Bertin et al. (2012a).

is a surge overflowing method, where the water volume discharge over the dykes is computed based on time series of modeled water levels, thereby consisting of a semi-dynamic method. For the two first methods (SM1 and SM2), the cells of the DTM are considered as flooded if their elevation is below the maximum sea level and only if they are connected to an adjacent cell that is flooded or connected to open water.

\subsubsection{Static flood modeling (methods SM1 and SM2)}

The first step of the static flood modeling was to isolate the 27 marshes by extracting DTM cells below a $5 \mathrm{~m}$ NGF limit. For each of the 27 obtained DTM, two "water surface rasters" were created: (1) a first based on the maximum water level value measured at La Pallice tide gauge (SM1) and (2) a second based on space-varying maximum water levels retrieved 
from the storm surge modeling system (SM2). To compute differences between marsh DTMs and their associated water surface rasters, the Environmental Systems Research Institute's (ESRI's) ArcGIS 10 software along with the Spatial Analyst extension was used. The raster calculator function was used to compute cell by cell the differences between marshes DTMs and water surface rasters. From these resulting rasters, polygons surrounding the negative value regions were then created and only those directly connected to the open sea were kept, representing the flooded areas identified from static flood modeling. Two rules of pixels connectivity in rasters exist: the "four-side rule", where the grid cell is connected if any of its cardinal directions is adjacent to a flooded cell, and the "eight-side rule", where the grid cell is connected if its cardinal and diagonal directions are connected to a flooded grid cell (Poulter and Halpin, 2008). In this study, the connectivity was preserved using an eight-side rule.

\subsubsection{The surge overflowing discharge and volume on dykes (method SO)}

A semi-dynamic approach, based on the computation of surge overflowing discharges and volumes over the dykes (method SO), was applied to two marshes where the two SM methods strongly overestimate flooding predictions. This method was based on an approach validated by the CETMEF (French marine and fluvial technical study center), using a hydrodynamic numerical modeling system in a marsh flooded during Xynthia (CETMEF, 2010). The computation of discharges over the dykes uses the rectangular weir discharge equation of Kindsvater and Carter (1957):

$Q=\mu . L .(2 . g)^{1 / 2} \cdot h^{3 / 2}$

where $Q$ is the water discharge in $\mathrm{m}^{3} \mathrm{~s}^{-1}, \mu$ is the adimensional discharge coefficient (equal to 0.4 ), $L$ is the length of overflowed dyke in $\mathrm{m}, g$ is the acceleration of gravity in $\mathrm{m} . \mathrm{s}^{-2}$, and $h$ is the water depth over the dyke in $\mathrm{m}$, calculated by subtracting the dyke crest height to time series of modeled sea level at the closest computational node. This method is very sensitive to the length of overflowed dyke and is limited to marshes bounded by straight dykes. Discharges were computed every ten minutes in order to take into account the temporal variations of $h$. The resulting discharges were then used to compute the total overflowing water volume. Since the objective was to delineate the flooded areas, those overflowing water volumes had to be spread within the marshes. With this aim, iterative static flood modeling was performed, increasing step by step the water level until the corresponding water volume matched the overflowing water volume.

\subsection{Accuracy assessment of flood models}

There are many ways to evaluate the performance of flood inundation models in terms of flood extent (Schumann et al., 2009). Among these, the following are widely used: the first one compares modeled and observed flood surface areas (Aronica et al., 2002; Bates et al., 2005; Horritt, 2006; Gallien et al., 2012; Smith et al., 2011); the second one compares water levels at the observed and modeled flood outlines (Mason et al., 2009). The comparison of water levels at the observed and modeled flood outlines is not suitable because the topography of the studied marshes is almost flat. Thereby, changes in flood outlines are not necessarily associated with changes in topography and the use of water levels at modeled and observed flood outlines is not relevant. The comparison between modeled and observed surface areas was preferred. In this study, the fit measurement $(F)$ described by Aronica et al. (2002) and Horritt (2006) was used:

$F=A /(A+B+C)$

In this equation, $A$ is the area correctly predicted as flooded by the model, $B$ is the area predicted as flooded while being dry in the observation (overprediction) and $C$ is the flooded area not predicted by the model (underprediction). $F$ is equal to 1 when observed and predicted areas coincide exactly, and equal to 0 when no overlap between predicted and observed areas exists. Gallien et al. (2011, 2012) described several fit measures based on surface areas. We selected Eq. (2), which is generally recommended for both deterministic and uncertain calibration because it considers underprediction and overprediction equally undesirable (Schumann et al., 2009). We arbitrarily defined good fit measurements for F-values $\geq 0.7$, intermediate fit measurements for $0.5 \leq \mathrm{F}$-values $<0.7$ and bad fit measurements for F-values $<0.5$.

A multiple linear regression analysis (MLRA) was carried out in order to investigate the relationship between morphological parameters and land uses and the F-values. Five parameters that seemed to be a priori the most relevant were chosen: (1) the maximum distance between the coastline and the landward boundary of the marsh (D); (2) the surface area of the marsh; (3) the mean topography of the marsh; (4) the urbanization rate, computed for each marsh using the Corine land cover database (www.eea.europa.eu); and (5) a land reclamation rate since 1824 , calculated using a coastline dating from 1824.

\section{Results}

\subsection{Fit measurements for static flood modeling (SM1 and SM2)}

Fit measurements for the modeled flooded areas using methods SM1 and SM2 show a wide variability (Table 4). For the 21 small marshes, 7 have good, 6 intermediate and 8 bad F-values when using method SM1, with corresponding F-values ranging from 0 to 0.88 . Method SM2 slightly improves the prediction, with 8 good, 6 intermediate and 7 bad 
F-values (ranging from 0.10 to 0.88 ). For the 5 large marshes, F-values range from 0.09 to 0.75 using method SM1, and from 0.09 to 0.78 using method SM2. Good F-values are obtained for 2 marshes and bad F-values are obtained for 3 marshes using method SM1 and SM2. For the only very large marsh, $F$ is equal to 0.16 (bad value) using both SM1 and SM2 methods.

The performances of both methods (SM1 and SM2) with respect to the size of the marshes are summarized in Table 5, where mean F-values are calculated for small, large and very large marshes and finally for all marshes. Best F-values are observed for small marshes using method SM2, while SM1 and SM2 give bad F-value for the very large marsh.

\subsection{Multiple linear regression analyses}

In order to investigate the relationship between morphological parameters and land uses and the F-values distribution, a multiple linear regression analysis was realized for the F-values, computed using method SM2. The result of the MLRA shows that the 5 parameters considered (distance between the coastline and the landward boundary of the marsh (D), surface area, mean topography, urbanization rate, and land reclamation rate) explain $57 \%$ of the variance of the F-values. After analyzing the impact of the parameters separately, it appears that only two of them have a significant influence on F variance: the distance between the coastline and the landward boundary of the marsh (D), which is the more significant parameter, and the surface area of the marsh. These two parameters explain $44 \%$ of the variance of Fvalues. This analysis reveals that best F-values occur for marshes with a small (D) and/or a small surface area. Other parameters (mean topography, coastline migration rate, and urbanization) are not significantly correlated with F-values (Fig. 4b, d, e).

\subsection{Focus on examples}

As the 27 studied marshes include small, large and very large marshes, we focus on representative examples of each category. For small and large marshes, two examples are selected, respectively showing good (Ile Madame no. 12, Seudre Estuary no. 25) and bad F-values (Coup de Vague no. 08, Brouage no. 24), for SM methods. The SO method is only applied to marsh examples where the SM1 and SM2 methods resulted in poor flooding predictions (Brouage no. 24 and Poitevin Marsh no. 27).

\subsubsection{Two examples of well-predicted flood extent, using static flood modeling}

The Ile Madame Marsh (no. 12; Fig. 5) is a small marsh (0.54 $\mathrm{km}^{2}$ ) emplaced on a small island located immediately to the south of the Charente River mouth. The observed flooded area during Xynthia at Ile Madame Marsh was $0.47 \mathrm{~km}^{2}$. Modeled flooded surface areas are $0.52 \mathrm{~km}^{2}$ by using SM1
(4.50 m NGF maximum water level) and SM2 (4.45 m NGF maximum water level). For the fit measurement calculation, the surface area correctly predicted as flooded by the model (A) is $0.46 \mathrm{~km}^{2}$, the overprediction (B) is $0.05 \mathrm{~km}^{2}$ and the underprediction $(C)$ is $0.01 \mathrm{~km}^{2}$ using both methods SM1 and SM2. The resulting F-values are 0.88 for SM1 and SM2.

The Seudre Estuary Marsh (no. 25; Fig. 6) is a large marsh $\left(125 \mathrm{~km}^{2}\right)$ bordering the Seudre River estuary. According to the observations, $88.31 \mathrm{~km}^{2}$ of the surface area of this marsh was flooded during Xynthia. The flooded surface areas estimated by the static flood modeling are $118 \mathrm{~km}^{2}$ and $111 \mathrm{~km}^{2}$ using SM1 (4.50 m NGF maximum water level) and SM2 (4.14 m NGF maximum water level), respectively. Using SM1, the fit measurement shows a $88.04 \mathrm{~km}^{2}$ surface area correctly predicted (A), a $29.47 \mathrm{~km}^{2}$ surface area overpredicted (B) and a $0.27 \mathrm{~km}^{2}$ surface area underpredicted (C). Using SM2, A, B and C are equal to $87.55 \mathrm{~km}^{2}, 23.76 \mathrm{~km}^{2}$ and $0.76 \mathrm{~km}^{2}$, respectively. The F-values are 0.75 and 0.78 using SM1 and SM2, respectively.

\subsubsection{Improvement of flooding prediction using spatial variations of sea level from a storm surge modeling system (SM2)}

The Coup de Vague Marsh (no. 8; Fig. 7), located in the northern part of the study area, is a small marsh $\left(0.48 \mathrm{~km}^{2}\right)$ where the observed flooded surface area during Xynthia was $0.44 \mathrm{~km}^{2}$. While method SM1 (4.50 m NGF maximum water level) does not flood this marsh at all (no black dotted line on Fig. 7), $0.43 \mathrm{~km}^{2}$ are supposed to be flooded following the result of method SM2. Therefore, the resulting fit measurement for method SM1 is $0\left(A=B=0 \mathrm{~km}^{2}\right.$ , $\mathrm{C}=0.44 \mathrm{~km}^{2}$ ). Method SM2 (4.75 m NGF maximum water level) gives correctly-predicted, overpredicted and underpredicted flooded surface areas of $0.39 \mathrm{~km}^{2}, 0.04 \mathrm{~km}^{2}$ and $0.05 \mathrm{~km}^{2}$, respectively. Thus, method SM2 considerably increases the F-value for this marsh (from 0 to 0.82 ).

\subsubsection{Improvement of flooding predictions using surge overflowing method (SO)}

The results of the MLRA revealed that static flood modeling gives bad fit measurement values for marshes characterized by a large distance between the coastline and the landward boundary of the marsh, and a large surface area. An improvement of flooding predictions is tentatively applied to two marshes bounded by straight dykes (Brouage no. 24 and Poitevin Marsh no. 27). The comparison between fit measurements from SM1, SM2 and SO methods shows that the SO method significantly improves flooding predictions (Table 6).

The Brouage Marsh (no. 24; Fig. 8) is a large marsh $\left(120 \mathrm{~km}^{2}\right)$ located on the eastern side of a tidal bay, the Marennes-Oléron Bay. Here, the observed flooded surface area during Xynthia was $28.75 \mathrm{~km}^{2}$. Static flood modeling 
Table 4. Results of fit measurements computation for the 27 marshes, classified into three classes: small marshes (S), large marshes (L) and very large marshes (XL), using methods SM1 and SM2.

\begin{tabular}{|c|c|c|c|c|c|c|c|c|c|}
\hline \multirow[b]{2}{*}{ Marsh no. } & \multirow[b]{2}{*}{ Marsh classes } & \multicolumn{4}{|c|}{ Fit measurement from method SM1 } & \multicolumn{4}{|c|}{ Fit measurement from method SM2 } \\
\hline & & $\mathrm{A}\left(\mathrm{km}^{2}\right)$ & $\mathrm{B}\left(\mathrm{km}^{2}\right)$ & $\mathrm{C}\left(\mathrm{km}^{2}\right)$ & $\mathrm{F}$ & $\mathrm{A}\left(\mathrm{km}^{2}\right)$ & $\mathrm{B}\left(\mathrm{km}^{2}\right)$ & $\mathrm{C}\left(\mathrm{km}^{2}\right)$ & $\mathrm{F}$ \\
\hline 1 & $\mathrm{~S}$ & 0.04 & 0.01 & 0.00 & 0.72 & 0.04 & 0.01 & 0.00 & 0.72 \\
\hline 2 & $\mathrm{~S}$ & 0.08 & 0.02 & 0.02 & 0.65 & 0.07 & 0.02 & 0.03 & 0.62 \\
\hline 3 & $\mathrm{~S}$ & 0.14 & 0.02 & 0.15 & 0.46 & 0.14 & 0.01 & 0.16 & 0.44 \\
\hline 4 & $\mathrm{~S}$ & 0.07 & 0.14 & 0.01 & 0.32 & 0.06 & 0.11 & 0.02 & 0.34 \\
\hline 5 & $\mathrm{~S}$ & 0.25 & 0.01 & 0.04 & 0.84 & 0.26 & 0.02 & 0.03 & 0.85 \\
\hline 6 & $\mathrm{~S}$ & 0.25 & 0.02 & 0.04 & 0.79 & 0.24 & 0.02 & 0.05 & 0.77 \\
\hline 7 & $\mathrm{~S}$ & 0.16 & 0.21 & 0.01 & 0.42 & 0.16 & 0.21 & 0.01 & 0.43 \\
\hline 8 & $\mathrm{~S}$ & 0.00 & 0.00 & 0.44 & 0.00 & 0.39 & 0.04 & 0.05 & 0.82 \\
\hline 9 & $\mathrm{~S}$ & 0.25 & 0.12 & 0.09 & 0.55 & 0.23 & 0.10 & 0.10 & 0.54 \\
\hline 10 & $\mathrm{~S}$ & 0.35 & 0.12 & 0.01 & 0.74 & 0.36 & 0.12 & 0.01 & 0.73 \\
\hline 11 & $\mathrm{~S}$ & 0.39 & 0.10 & 0.07 & 0.69 & 0.39 & 0.09 & 0.08 & 0.69 \\
\hline 12 & $\mathrm{~S}$ & 0.46 & 0.05 & 0.01 & 0.88 & 0.46 & 0.05 & 0.01 & 0.88 \\
\hline 13 & $\mathrm{~S}$ & 0.11 & 0.98 & 0.01 & 0.10 & 0.11 & 0.96 & 0.01 & 0.10 \\
\hline 14 & $\mathrm{~S}$ & 1.44 & 0.13 & 0.08 & 0.87 & 1.42 & 0.12 & 0.09 & 0.87 \\
\hline 15 & $\mathrm{~S}$ & 1.37 & 0.32 & 0.02 & 0.80 & 1.37 & 0.35 & 0.02 & 0.79 \\
\hline 16 & $\mathrm{~S}$ & 0.38 & 2.02 & 0.00 & 0.16 & 0.38 & 1.56 & 0.00 & 0.19 \\
\hline 17 & $\mathrm{~S}$ & 0.22 & 0.31 & 0.33 & 0.26 & 0.21 & 0.30 & 0.34 & 0.25 \\
\hline 18 & $\mathrm{~S}$ & 3.26 & 4.18 & 0.12 & 0.43 & 3.25 & 4.07 & 0.13 & 0.44 \\
\hline 19 & $\mathrm{~S}$ & 9.09 & 4.22 & 0.03 & 0.68 & 9.08 & 4.13 & 0.04 & 0.69 \\
\hline 20 & $\mathrm{~S}$ & 7.80 & 5.21 & 0.08 & 0.60 & 7.79 & 4.95 & 0.10 & 0.61 \\
\hline 21 & $\mathrm{~S}$ & 10.61 & 9.92 & 0.09 & 0.51 & 10.61 & 9.93 & 0.08 & 0.51 \\
\hline 22 & $\mathrm{~L}$ & 16.72 & 38.90 & 0.09 & 0.30 & 16.70 & 37.92 & 0.10 & 0.31 \\
\hline 23 & $\mathrm{~L}$ & 46.91 & 19.15 & 1.33 & 0.70 & 46.84 & 18.84 & 1.40 & 0.70 \\
\hline 24 & $\mathrm{~L}$ & 28.61 & 90.63 & 0.13 & 0.24 & 28.59 & 89.75 & 0.16 & 0.24 \\
\hline 25 & $\mathrm{~L}$ & 88.04 & 29.47 & 0.27 & 0.75 & 87.55 & 23.76 & 0.76 & 0.78 \\
\hline 26 & $\mathrm{~L}$ & 13.56 & 139.10 & 0.32 & 0.09 & 13.54 & 138.53 & 0.34 & 0.09 \\
\hline 27 & XL & 156.22 & 789.63 & 1.99 & 0.17 & 156.80 & 804.56 & 1.41 & 0.16 \\
\hline
\end{tabular}

Table 5. Mean F-values for all marshes and for the three surface area classes.

\begin{tabular}{lll}
\hline Marsh classes & $\begin{array}{l}\text { Mean F-value using } \\
\text { method SM1 }\end{array}$ & $\begin{array}{l}\text { Mean F-value using } \\
\text { method SM2 }\end{array}$ \\
\hline all marshes & 0.51 & 0.54 \\
small marshes & 0.55 & 0.58 \\
large marshes & 0.41 & 0.42 \\
very large marsh & 0.17 & 0.16 \\
\hline
\end{tabular}

results show a $119.24 \mathrm{~km}^{2}$ flooded surface area using SM1 (4.50 m NGF maximum water level) and a $118.35 \mathrm{~km}^{2}$ flooded surface area using SM2 (4.43 m NGF maximum water level). Fit measurements reveal that both methods clearly overpredict the flood (Fig. 8). The area correctly predicted as flooded by the model (A) is $28.61 \mathrm{~km}^{2}$, the overprediction (B) is $90.63 \mathrm{~km}^{2}$ and the underprediction (C) is $0.13 \mathrm{~km}^{2}$ using method SM1, and $\mathrm{A}, \mathrm{B}$ and $\mathrm{C}$ are equal to $28.59 \mathrm{~km}^{2}$, $89.75 \mathrm{~km}^{2}$ and $0.16 \mathrm{~km}^{2}$ using method SM2. The bad Fvalues (0.24 for SM1 and SM2) are thus explained by this large overprediction. Equation (1) allows for computing a $24.56 \times 10^{6} \mathrm{~m}^{3}$ overflowing water volume (Table 2 ). After the spread of this water volume in the marsh, method SO allows for increasing the F-value to 0.40 , with an A-value of $19.88 \mathrm{~km}^{2}$, a B-value of $21.28 \mathrm{~km}^{2}$ and a C-value of $8.87 \mathrm{~km}^{2}$.

The Poitevin Marsh (no. 27; Fig. 9) is the largest marsh $\left(997 \mathrm{~km}^{2}\right)$ in the study area, where the Lay and the Sèvre Niortaise rivers flow. During Xynthia, $158.21 \mathrm{~km}^{2}$ of this marsh were flooded. According to the static flood modeling, $945.85 \mathrm{~km}^{2}$ and $961.36 \mathrm{~km}^{2}$ are predicted as flooded using methods SM1 (4.50 m NGF maximum water level) and SM2 (4.75 m NGF maximum water level), respectively. The result of the fit measurement between surface areas using method 

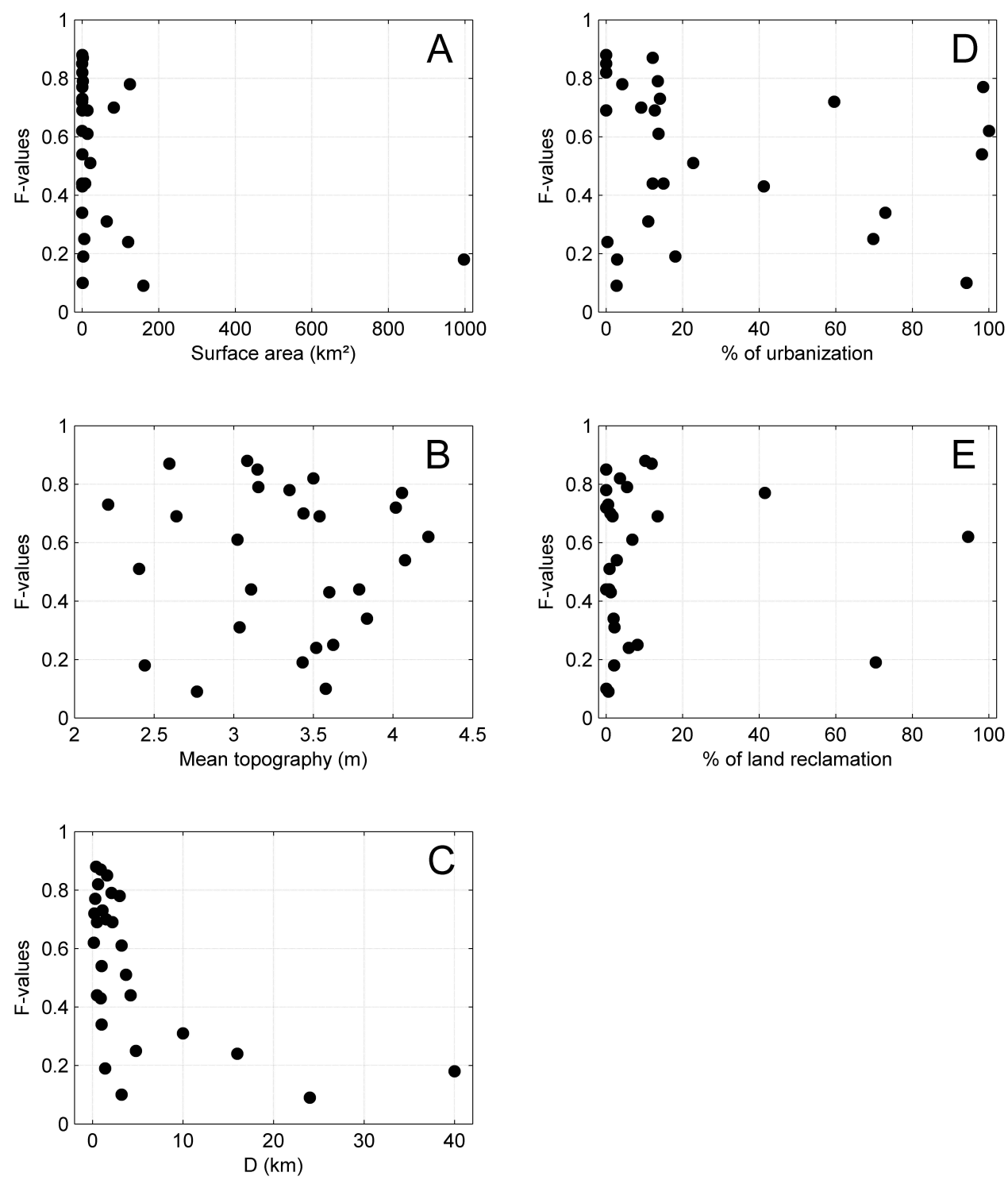

Fig. 4. F-values computed using method SM2 for the 27 marshes regarding: (A) surface area, (B) mean topography, (C) distance between the coastline and the landward boundary of the marsh (D), (D), urbanization rate, (E) land reclamation rate.

Table 6. Results of fit measurements computation for Brouage and Poitevin marshes, using method SO and best F-values using methods SM1 and SM2.

\begin{tabular}{llllllll}
\hline Marsh no. & $\begin{array}{l}\text { Surge overflowing wa- } \\
\text { ter volume }\left(10^{6} \mathrm{~m}^{3}\right)\end{array}$ & $\begin{array}{l}\text { Flooded area using } \\
\text { surge overflowing over } \\
\text { dykes }\left(\mathrm{km}^{2}\right)\end{array}$ & $\begin{array}{l}\mathrm{A} \\
\left(\mathrm{km}^{2}\right)\end{array}$ & $\begin{array}{l}\mathrm{B} \\
\left(\mathrm{km}^{2}\right)\end{array}$ & $\begin{array}{l}\mathrm{C} \\
\left(\mathrm{km}^{2}\right)\end{array}$ & $\begin{array}{l}\mathrm{F} \text { using } \\
\text { method } \\
\text { SO }\end{array}$ & $\begin{array}{l}\text { F using method SM1 or } \\
\text { SM2 }\end{array}$ \\
\hline 24 & 21.56 & 41.16 & 19.88 & 21.28 & 8.87 & 0.41 & 0.24 \\
\hline 27 & 62.89 & 96.04 & 71.38 & 24.66 & 86.83 & 0.39 & 0.17 \\
\hline
\end{tabular}

SM1 gives a $156.22 \mathrm{~km}^{2}$ correctly predicted surface area (A), a $789.63 \mathrm{~km}^{2}$ overpredicted surface area (B) and a $1.99 \mathrm{~km}^{2}$ underpredicted surface area $(\mathrm{C})$, while the method SM2 gives $\mathrm{A}, \mathrm{B}$ and $\mathrm{C}$ respectively equal to $156.80 \mathrm{~km}^{2}, 804.56 \mathrm{~km}^{2}$ and $1.40 \mathrm{~km}^{2}$. Once again, the bad F-values (0.17 for SM1 and 0.16 for SM2) are explained by these large overpredictions. As for the Brouage Marsh case, after the spread of a $62.89 \times 10^{6} \mathrm{~m}^{3}$ water volume computed from Eq. (1) (Table 2), method SO gives a higher F-value of 0.39. The surface area correctly predicted is $71.38(\mathrm{~A})$, while the overpredicted 


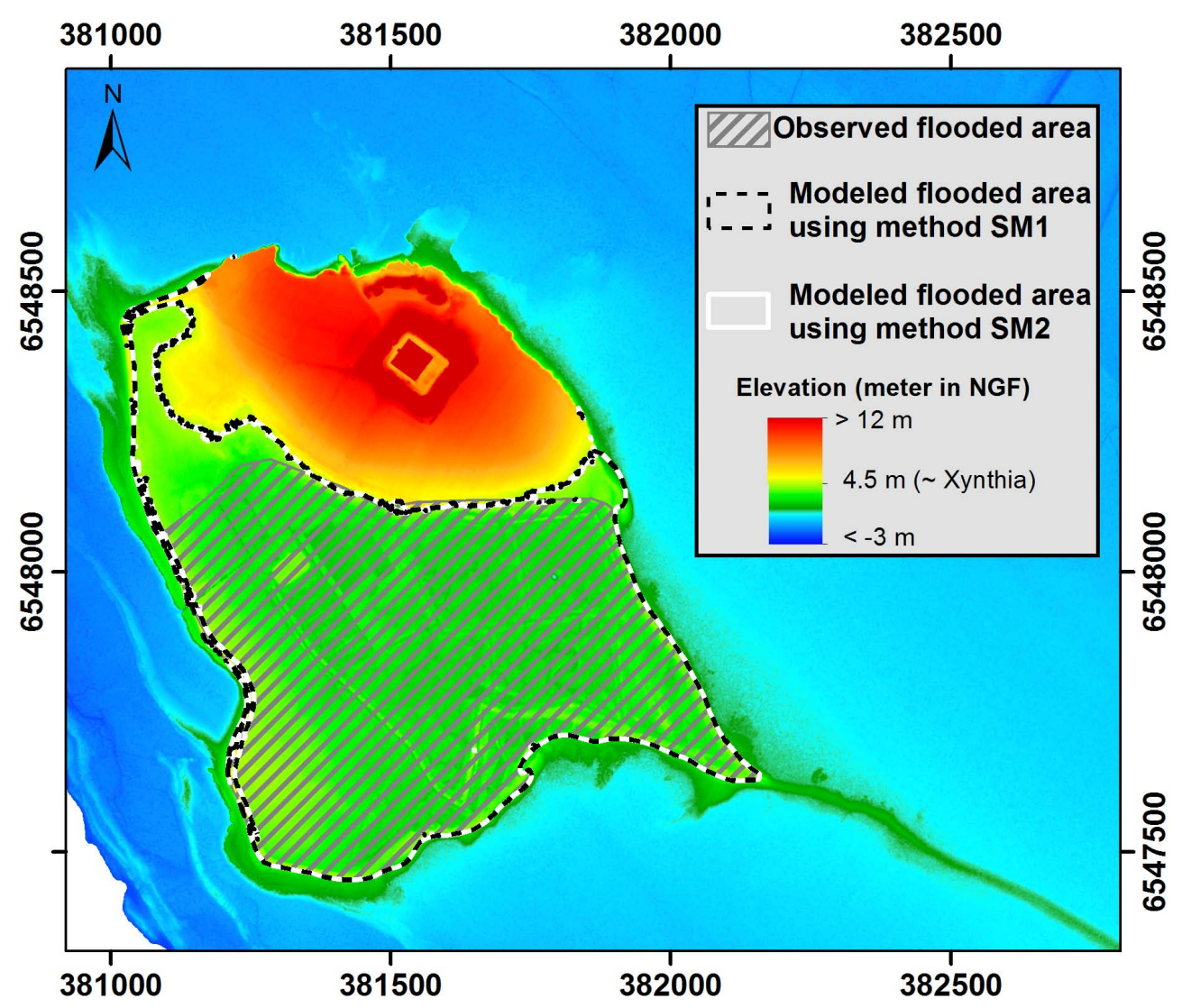

Fig. 5. Digital Terrain Model (DTM) of the Ile Madame Marsh (no. 12) showing the observed flooded area (hatched grey lines), the modeled flooded area using method SM1 (black dotted line) and the modeled flooded area using method SM2 (white line).

surface area is $24.66 \mathrm{~km}^{2}$ and the underpredicted surface area is $86.83 \mathrm{~km}^{2}$.

\section{Discussion}

The availability of high-resolution LiDAR elevation data together with accurate observations of post Xynthia storm flooded areas provided the opportunity to evaluate rasterbased flood modeling methods on a wide variety of coastal low lands areas that were flooded during this storm.

\subsection{Added value of space-varying maximum sea levels extracted from the modeling system}

Considering the spatial variability of maximum water levels reached during the Xynthia storm (about $1 \mathrm{~m}$, Fig. 3), one could expect that using sea level measured at La Pallice tide gauge (SM1) would appear as a strong weakness compared to using space-varying modeled sea levels (SM2). On the contrary, F-values only increased drastically at one marsh and no significant changes can be observed for the others marshes when using modeled space-variable sea levels. The only example where flood predictions are considerably improved with the SM2 method is the Coup de Vague
Marsh (no. 8, Table 4 and Fig. 7). This better prediction with the SM2 method is related to the water level value used for the prediction, which is slightly below the dyke minimum height (4.60 m NGF) in SM1 (4.5 m NGF) and slightly above in SM2 (4.75 m NGF, Table 3). This study would suggest that spatial variations of maximum sea level elevation have a limited impact on the prediction of the flooding. Nevertheless, this conclusion may be valid only for the present case study where maximum water level, in front of the flooded marshes, varies from less than $0.5 \mathrm{~m}$. Other studies have reported much larger spatial variability of sea levels, for example, along the coastlines of Florida, Alabama, Mississippi and Louisiana (Fritz et al., 2007), South Carolina (Peng et al., 2006), or Texas (Rego and Li, 2010). Under such conditions, using spatial variable sea level may improve flooding prediction significantly.

\subsection{Applicability of the static flood modeling methods according to the morphology of the marshes}

The MRLA analysis showed that the high variability of F-values obtained using static flood modeling methods was related to morphological parameters of the considered marshes. Among the morphological and land use parameters, 


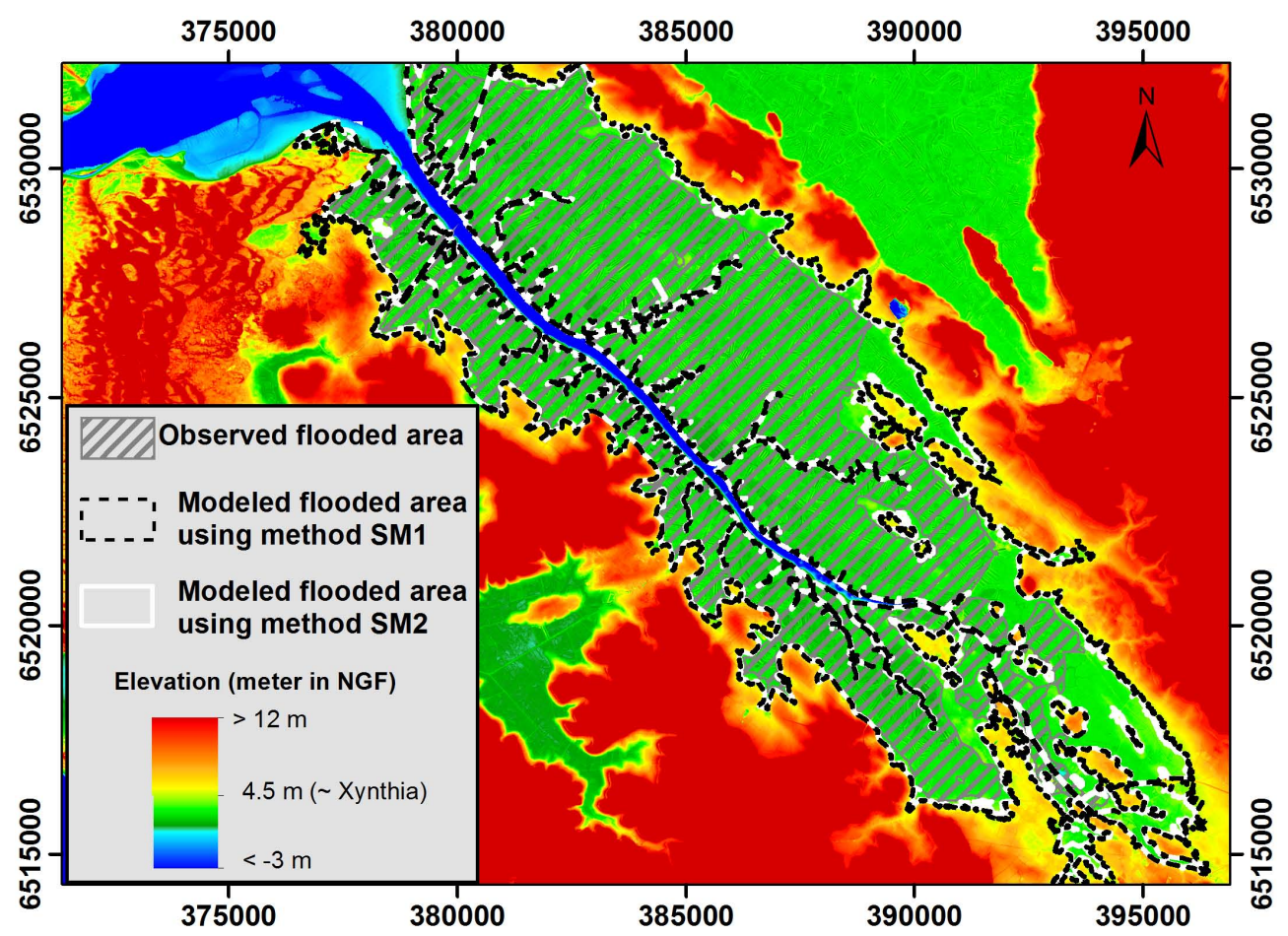

Fig. 6. Digital Terrain Model (DTM) of the Seudre Estuary Marsh (no. 25) showing the observed flooded area (hatched grey lines), the modeled flooded area using method SM1 (black dotted line) and the modeled flooded area using method SM2 (white line).

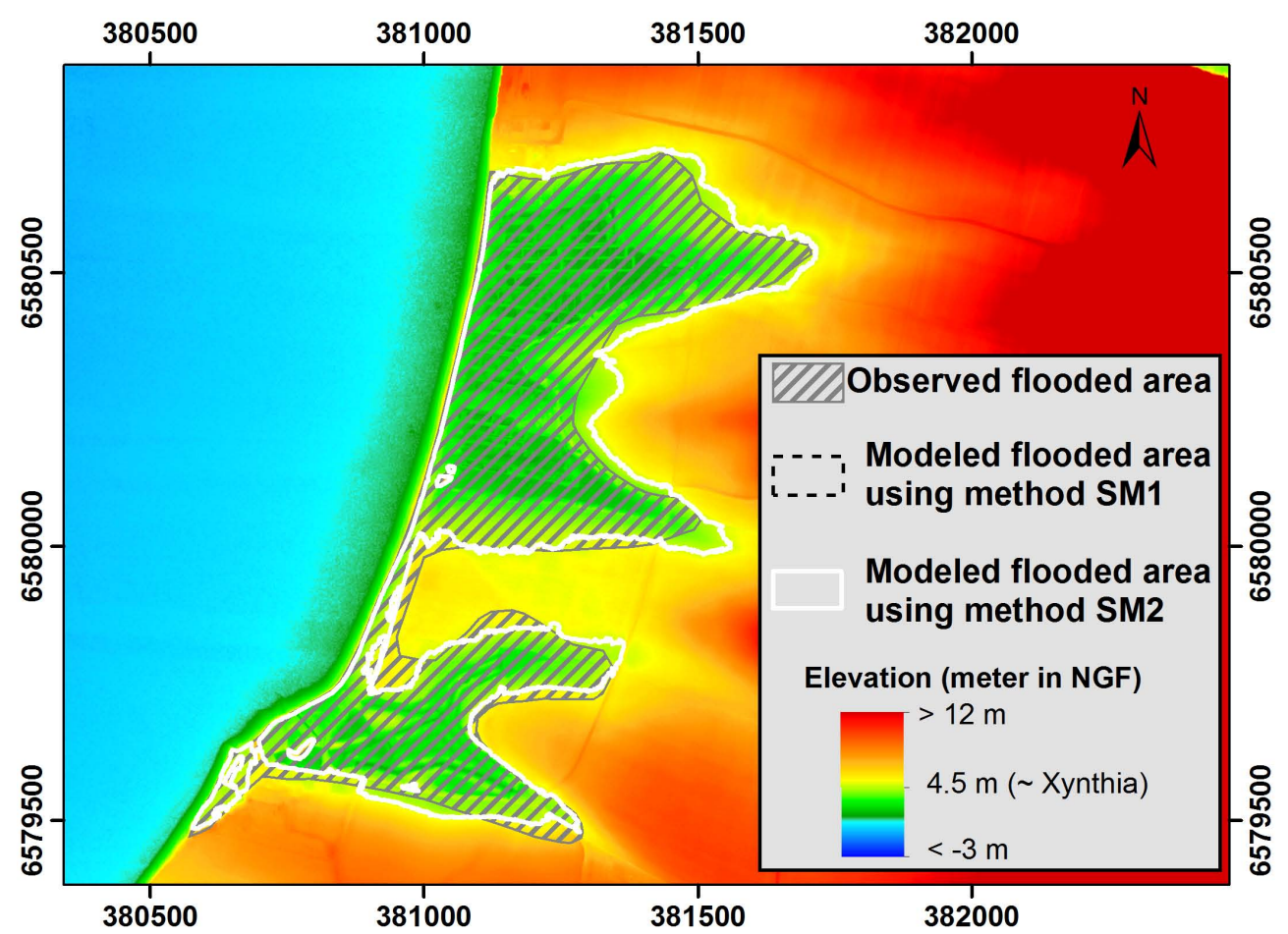

Fig. 7. Digital Terrain Model (DTM) of the Coup de Vague Marsh (no. 8) showing the observed flooded area (hatched grey lines), the modeled flooded area using method SM1 (black dotted line) and the modeled flooded area using method SM2 (white line). 


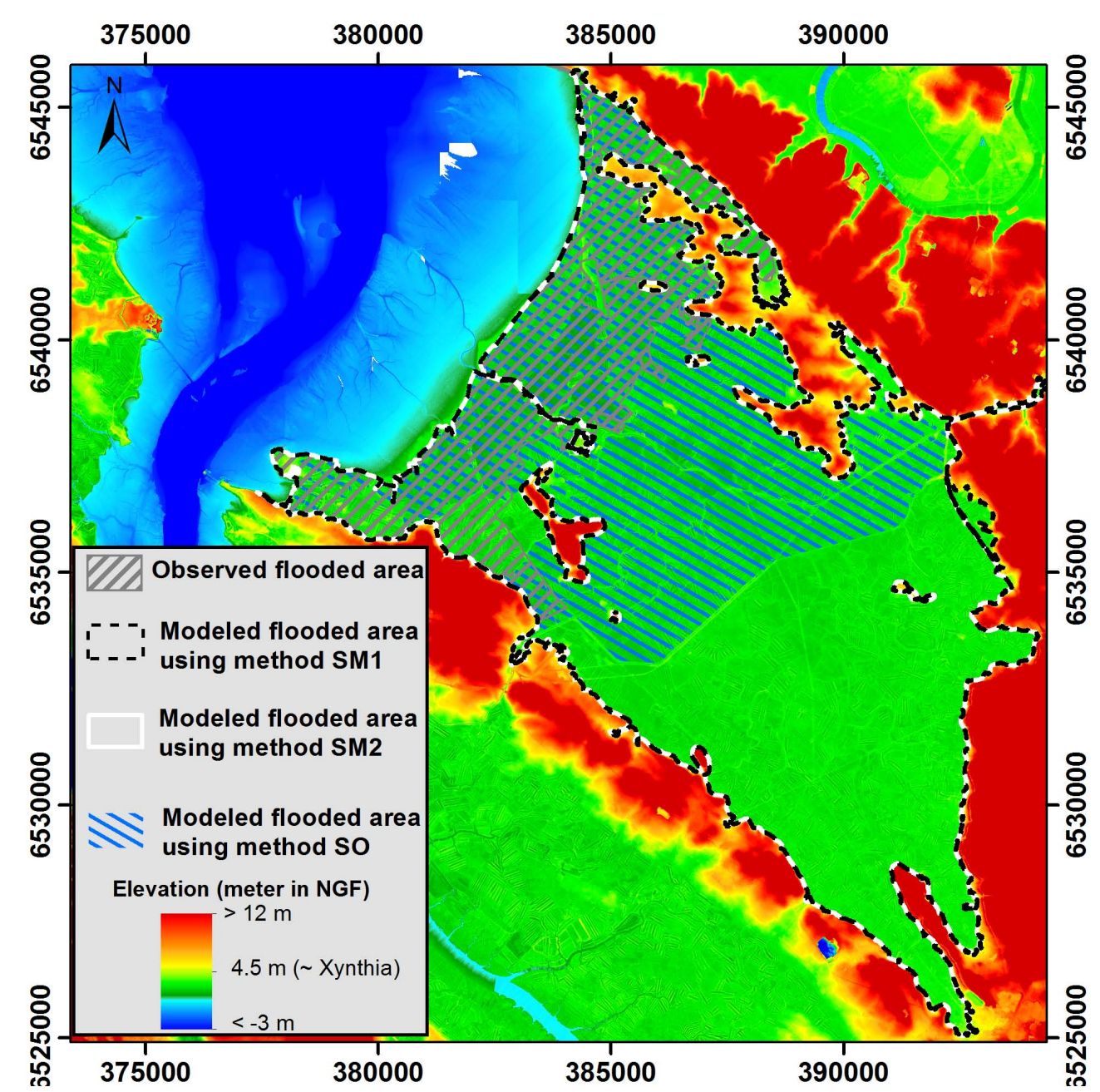

Fig. 8. Digital Terrain Model (DTM) of the Brouage Marsh (no. 24) showing the observed flooded area (hatched grey lines), the modeled flooded area using method SM1 (black dotted line), the modeled flooded area using method SM2 (white line) and the modeled flooded area using method SO (hatched blue lines).

only two of them explain $44 \%$ of the F-values variance: the distance between the coastline and the landward boundary of the marsh (D), and the surface area of the marsh (Fig. 4a and c). The correlation between F-values and D is explained because static flood modeling methods do not take into account the kinematics of the flow and are based on the assumption that the flooding is instantaneous. In the case of small marshes, the flooding volume is small and the marsh is filled after a short period of time. Moreover, in the study area, marshes are usually bounded by steep paleo-coastlines corresponding to ancient sea cliffs. Such morphology for the inner boundary of marshes implies that once completely flooded, increase in water level will lead to very small variations in flooded surface areas. In the case of large marshes with estuaries, the distance between the coastline and the landward boundary of the marsh (D) is reduced and the length of overflowing (L from Eq. 1) is important, leading to a large surge overflowing volume. In those cases, the flooding is fast and can be considered as nearly instantaneous. Consequently, static flood modeling methods perform well for this kind of large marshes

In the case of large marshes without estuaries or with an estuary but characterized by a long distance between the coastline and the landward boundary of the marsh (D), the potential flooded volume is large in comparison to the observed surge overflowing volume, because the length of overflowing (L) is small with respect to the marsh surface area. In addition, the distance between the coastline and the landward boundary of the marsh (D) is long. Thus, the duration needed to flood the entire marsh area located below the sea level is considerably longer than the overflowing duration during the Xynthia storm. For instance, the flooding of the dykes lasted less than a few hours because of the tide-induced sea level variations. Consequently, static flood modeling, which considers the flooding as instantaneous, considerably overpredicts the extension of flooded areas, as already shown by 


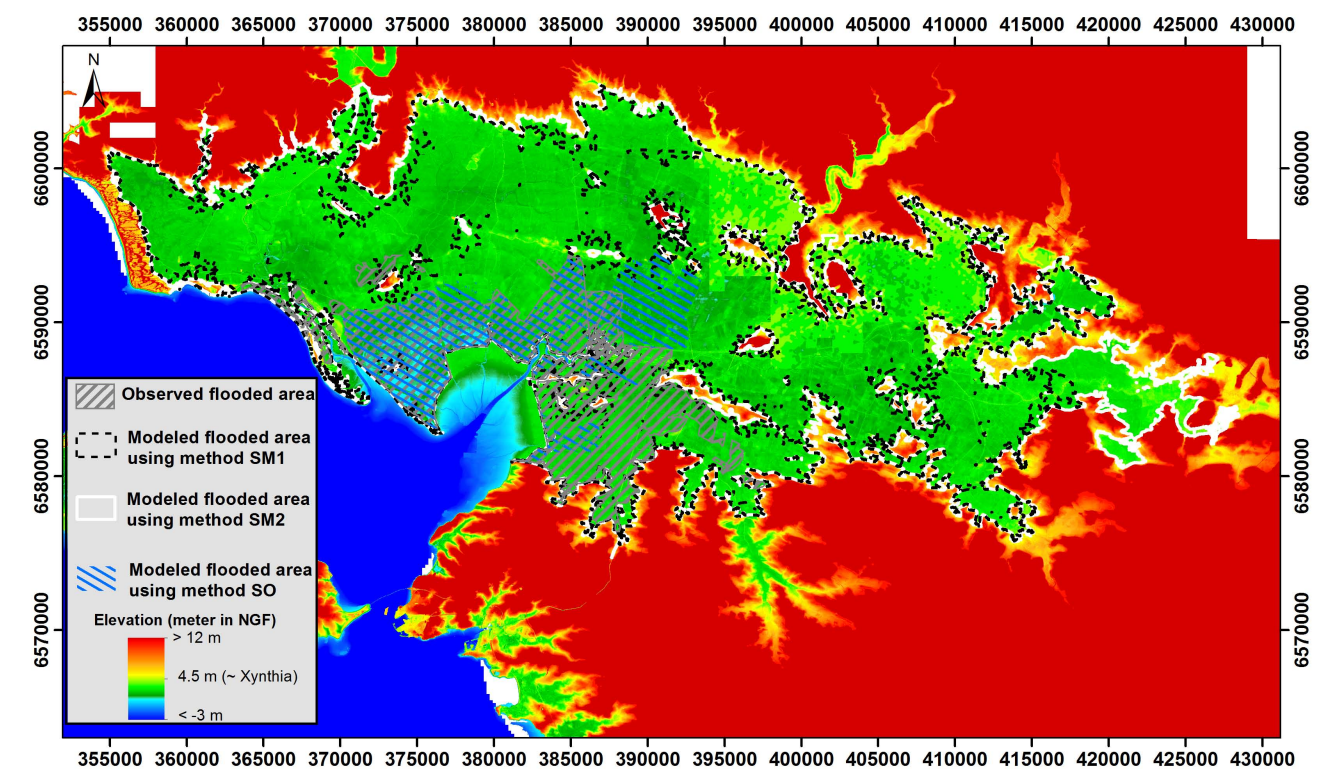

Fig. 9. Digital Terrain Model (DTM) of the Poitevin Marsh (no. 27) showing the observed flooded area (hatched grey lines) and the modeled flooded area from methods SM1 (dashed black line), SM2 (solid white line) and SO (hatched blue lines).

Apel et al. (2009), Bates and De Roo (2000) or Gallien et al. (2011).

From this study, it appears that static methods seem to be suitable for small marshes (Fig. 4a) and for large marshes drained by an estuary with a small distance between the coastline and the landward boundary of the marsh (Fig. 4c). The common morphological parameter for those marshes is the small distance between the coastline and the landward boundary of the marsh. This result can be generalized to coastal low lands at a global scale. In the case of narrow low lands commonly found along active margins and uplifted coastlines, and in the case of estuaries or back barrier lagoons bounded by narrow marshes, static flood modeling methods may be suitable. In contrast, this method will fail in predicting flood extension in cases of wide low lands such as those found in deltas and large land reclamation areas.

\subsection{Advantages and limitations of surge overflowing calculation}

Neglecting the kinematics aspect of the flooding is the main weakness of static inundation techniques. To overcome this limitation, a surge overflowing method (SO) was proposed. This method was applied to Brouage (no. 24) and Poitevin Marshes (no. 27), which are respectively examples of large and very large marshes with an estuary where static methods are not suitable. In both cases, this semi-dynamic method improves the prediction of the flooded areas (Table 6; Figs. 8 and 9). However, modeled flooded surface areas remain underestimated compared to observations for the Poitevin Marsh. Nevertheless, the storm surge modeling system employed in this study was developed to investigate storm surges at the scale of continental shelves in the NE Atlantic Ocean $(\sim 1000 \mathrm{~m}$ maximum resolution along the shoreline) Results recently obtained with a much higher spatial resolution ( $\sim 25 \mathrm{~m}$ along the shoreline) and a fully coupled approach suggest that nearshore wave-induced processes can locally rise water level by 0.2 to $0.4 \mathrm{~m}$ (Bertin et al., 2012b). Such differences may explain why SO method underpredicts the flooding in marshes exposed to large wind waves as in the case of the Poitevin Marsh, facing a relatively large fetch in the southwest direction (Fig. 1). The Brouage Marsh shows contrasted results, since the modeled flooded surface area from SO method is overestimated compared to the observed flooded area. This could be explained by the very complex multiple dyke system in this marsh (Fig. 8). In addition, the simple Eq. (1), used to compute overflowing discharge (Kindsvater and Carter, 1957), was designed for an idealized rectangular weir and cannot take into account the complexity of the dyke system in the Brouage Marsh.

The results obtained with the surge overflowing method suggest that this method can improve the flooding prediction significantly in the case of straight dykes if water levels are accurately predicted along the shoreline.

\section{Conclusions}

The aim of this study was to assess a raster-based static flood modeling method and a semi-dynamic method using surge overflowing volumes on a wide diversity of marshes that were flooded during Xynthia in the Pertuis Charentais. The comparison between predictions and observations (delineation of post-storm flooded areas) demonstrates that static 
methods can accurately map flooding under certain conditions. Thus, well predicted flooded areas by static flood modeling methods correspond to small marshes and large marshes drained by an estuary with a small distance between the coastline and the landward boundary of the marsh. Indeed, the underlying hypothesis of the static method, according to which the flooding is instantaneous, holds in those cases because the distance between the coastline and the landward boundary of the marsh is small (less than $3 \mathrm{~km}$ ). On the contrary, static flood modeling methods failed to reproduce flooded areas in the case of large marshes without estuaries or large marshes with a long distance between the coastline and the landward boundary of the marsh. Indeed, in those kinds of marshes, the instantaneous flooding hypothesis of the static method is unacceptable, as the distance between the coastline and the landward boundary of the marsh is large (more than $10 \mathrm{~km}$ ). Under these conditions, the computing of surge overflowing volumes can improve the flooding prediction significantly.

The raster-based methods assessed in this study are fast deploying methods, much lighter in terms of computation resources compared to the high resolution hydrodynamic storm surge and flood modeling system that requires massive parallel techniques (e.g. Bunya et al., 2010; Dietrich et al., 2011). In the case of narrow low lands and estuaries or back barrier lagoons bounded by narrow marshes, the methods assessed in this study may be attractive alternatives to design marine flooding early warning systems.

Acknowledgements. This work was supported by FEDER 341462010 and Conseil Général de Charente-Maritime. We would like to thank Frédéric Pouget, Fredéric Rousseaux, Cécilia PignonMussaud, Dorothée James and Jérôme Faucillon for their help on GIS. Thanks also go to Nicolas Bruneau for his help on the extraction of sea level elevations from the storm surge numerical model. We also would like to thank Clément Poirier for his support on statistical analysis. IGN is thanked for 2010 LiDAR data. SONEL (www.sonel.org) and REFMAR are thanked for sea level tide gauge measurements. Finally, the authors appreciated the comments of Guillem Chust as well as those of the anonymous reviewer, which greatly improved this manuscript.

Edited by: S. Tinti

Reviewed by: G. Chust and three anonymous referees

\section{References}

Allard, J., Chaumillon, É., Poirier, C., Sauriau, P.-G., and Weber, O.: Evidence of former Holocene sea level in the MarennesOléron Bay (French Atlantic coast), C. R. Geosci., 340, 306-314, doi:10.1016/j.crte.2008.01.007, 2008.

Apel, H., Aronica, G. T., Kreibich, H., and Thieken, A. H.: Flood risk analyses-how detailed do we need to be?, Nat. Hazards, 49, 79-98, doi:10.1007/s11069-008-9277-8, 2009.

Aronica, G., Bates, P. D., and Horritt, M. S.: Assessing the uncertainty in distributed model predictions using observed binary pat- tern information within GLUE, Hydrol. Process., 16, 2001-2016, doi:10.1002/hyp.398, 2002.

Banque hydro: Online French hydrological database accessible at http://www.hydro.eaufrance.fr/, (last access: 15 November 2012), 2012.

Bates, P. and De Roo, A. P. .: A simple raster-based model for flood inundation simulation, J. Hydrol., 236(1-2), 54-77, doi:10.1016/S0022-1694(00)00278-X, 2000.

Bates, P. D., Dawson, R. J., Hall, J. W., Horritt, M. S., Nicholls, R. J., Wicks, J., and Hassan, M. A. A. M.: Simplified twodimensional numerical modelling of coastal flooding and example applications, Coastal Eng., 52(9), 793-810, 2005.

Benavente, J., Del Río, L., Gracia, F., and Martínez-del-Pozo, J.: Coastal flooding hazard related to storms and coastal evolution in Valdelagrana spit (Cadiz Bay Natural Park, SW Spain), Cont. Shelf Res., 26, 1061-1076, 2006.

Bernatchez, P., Fraser, C., Lefaivre, D., and Dugas, S.: Integrating anthropogenic factors, geomorphological indicators and local knowledge in the analysis of coastal flooding and erosion hazards, Ocean Coast. Manage., 54, 621-632, doi:10.1016/j.ocecoaman.2011.06.001, 2011.

Bertin, X., Chaumillon, E., Sottolichio, A. and Pedreros, R.: Tidal inlet response to sediment infilling of the associated bay and possible implications of human activities: the Marennes-Oléron Bay and the Maumusson Inlet, France, Cont. Shelf Res., 25, 11151131, doi:10.1016/j.csr.2004.12.004, 2005.

Bertin, X., Castelle, B., Chaumillon, E., Butel, R., and Quique, R.: Longshore transport estimation and inter-annual variability at a high-energy dissipative beach: St. Trojan beach, SW Oléron Island, France, Cont. Shelf Res., 28, 1316-1332, doi:10.1016/j.csr.2008.03.005, 2008.

Bertin, X., Bruneau, N., Breilh, J.-F., Fortunato, A. B., and Karpytchev, M.: Importance of wave age and resonance in storm surges: The case Xynthia, Bay of Biscay, Ocean Model., 42, 1630, doi:10.1016/j.ocemod.2011.11.001, 2012a.

Bertin, X., Li, K., Roland, A., Breilh, J.-F., and Chaumillon, E.: Contributions des vagues dans la surcote associée à la tempête Xynthia, février 2010, 909-916, Editions Paralia, http: //www.paralia.fr/jngcgc/12_99_bertin.pdf, (last accessed: 22 June 2012b), 2012 b.

Billeaud, I., Chaumillon, E., and Weber, O.: Evidence of a major environmental change recorded in a macrotidal bay (MarennesOléron Bay, France) by correlation between VHR seismic profiles and cores, Geo-Mar. Lett., 25, 1-10, doi:10.1007/s00367004-0183-0, 2004.

Blake, E. S.: The deadliest, costliest and most intense United States tropical cyclones from 1851 to 2006 (and other frequently requested hurricane facts), NOAA Technical Memorandum NWS TPC 5, 43, 2007.

Brown, J. M., Souza, A. J., and Wolf, J.: An 11-year validation of wave-surge modelling in the Irish Sea, using a nested POLCOMS-WAM modelling system, Ocean Model., 33, 118128, 2010.

Bunya, S., Dietrich, J. C., Westerink, J. J., Ebersole, B. A., Smith, J. M., Atkinson, J. H., Jensen, R., Resio, D. T., Luettich, R. A., Dawson, C., Cardone, V. J., et al.: A High-Resolution Coupled Riverine Flow, Tide, Wind, Wind Wave, and Storm Surge Model for Southern Louisiana and Mississippi. Part I: Model Development and Validation, Mon. Weather Rev., 138(2), 345-377, 
doi:10.1175/2009MWR2906.1, 2010.

CETMEF (French Centre for Maritime and Fluvial Technical Studies): Analyse de l'événement Xynthia. Evaluation des volumes entrants par modélisation,http://http://www.cetmef. developpement-durable.gouv.fr/, 2010.

Chaumillon, E., Tessier, B., Weber, N., Tesson, M., and Bertin, X.: Buried sandbodies within present-day estuaries (Atlantic coast of France) revealed by very high resolution seismic surveys, Mar. Geol., 211, 189-214, doi:10.1016/j.margeo.2004.07.004, 2004.

Chaumillon, E., Proust, J.-N., Menier, D., and Weber, N.: Incisedvalley morphologies and sedimentary-fills within the inner shelf of the Bay of Biscay (France): A synthesis, Ocean. Bay Biscay, 72, 383-396, doi:10.1016/j.jmarsys.2007.05.014, 2008.

Chust, G., Galparsoro, I., Borja, Á., Franco, J., and Uriarte, A.: Coastal and estuarine habitat mapping, using LIDAR height and intensity and multi-spectral imagery, Estuar. Coast. Shelf Sci., 78, 633-643, doi:10.1016/j.ecss.2008.02.003, 2008.

Chust, G., Ángel Borja, Liria, P., Galparsoro, I., Marcos, M., Caballero, A., and Castro, R.: Human impacts overwhelm the effects of sea-level rise on Basque coastal habitats (N Spain) between 1954 and 2004, Estuar. Coastal Shelf Sci., 84, 453-462, doi:10.1016/j.ecss.2009.07.010, 2009.

Chust, G., Caballero, A., Marcos, M., Liria, P., Hernández, C., and Borja, Á.: Regional scenarios of sea level rise and impacts on Basque (Bay of Biscay) coastal habitats, throughout the 21st century, Estuarine Coastal Shelf Sci., 87, 113-124, doi:10.1016/j.ecss.2009.12.021, 2010.

Cook, A. and Merwade, V.: Effect of topographic data, geometric configuration and modeling approach on flood inundation mapping, J. Hydrol., 377, 131-142, 2009.

DAS, P. K.: Prediction Model for Storm Surges in the Bay of Bengal, Nature, 239, 211-213, doi:10.1038/239211a0, 1972.

DDTM-17: Éléments de mémoire sur la tempête Xynthia du 27 et 28 Février 2010 en Charente-Maritime, http://www.charente-maritime.equipement.gouv.fr/ elements-de-memoire-xynthia-r157.html, 2011.

Dietrich, J., Zijlema, M., Westerink, J., Holthuijsen, L., Dawson, C., Luettich Jr., R., Jensen, R., Smith, J., Stelling, G., and Stone, G.: Modeling hurricane waves and storm surge using integrallycoupled, scalable computations, Coast. Eng., 58, 45-65, 2011.

Fritz, H. M., Blount, C., Sokoloski, R., Singleton, J., Fuggle, A., McAdoo, B. G., Moore, A., Grass, C., and Tate, B.: Hurricane Katrina storm surge distribution and field observations on the Mississippi Barrier Islands, Estuar. Coast. Shelf Sci., 74, 12-20, doi:10.1016/j.ecss.2007.03.015, 2007

Gallien, T. W., Schubert, J. E., and Sanders, B. F.: Predicting tidal flooding of urbanized embayments: A modeling framework and data requirements, Coastal Eng., 58, 567-577, doi:10.1016/j.coastaleng.2011.01.011, 2011.

Gallien, T. W., Barnard, P. L., Van Ormondt, M., Foxgrover, A. C., and Sanders, B. F.: A Parcel-Scale Coastal Flood Forecasting Prototype for a Southern California Urbanized Embayment, J. Coastal Res., doi:10.2112/JCOASTRES-D-12-00114.1, 2012.

Gerritsen, H.: What happened in 1953? The Big Flood in the Netherlands in retrospect, Philos. Trans. R. Soc. London, Ser. A, 363, 1271-1291, doi:10.1098/rsta.2005.1568, 2005.

Goff, J. R., Lane, E., and Arnold, J.: The tsunami geomorphology of coastal dunes, Nat. Hazards Earth Syst. Sci., 9, 847-854, doi:10.5194/nhess-9-847-2009, 2009.
Haile, A. T. and Rientjes, T.: Effects of LiDAR DEM resolution in flood modelling: a model sensitivity study for the city of Tegucigalpa, Honduras, 36, 168-173, Enschede, the Netherlands, 2005.

Horritt, M. S.: A methodology for the validation of uncertain flood inundation models, J. Hydrol., 326, 153-165, doi:10.1016/j.jhydrol.2005.10.027, 2006.

IPCC: Climate Change 2007: Synthesis Report. Contribution of Working Groups I, II and III to the Fourth Assessment Report of the Intergovernmental Panel on Climate Change, IPCC., 2007.

Kennedy, A. B., Westerink, J. J., Smith, J. M., Hope, M. E., Hartman, M., Taflanidis, A. A., Tanaka, S., Westerink, H., Cheung, K. F., Smith, T., Hamann, M., Minamide, M., Ota, A., and Dawson, C.: Tropical cyclone inundation potential on the Hawaiian Islands of Oahu and Kauai, Ocean Model., 52-53, 54-68, doi:10.1016/j.ocemod.2012.04.009, 2012.

Kindsvater, C. and Carter, R.: Discharge characteristics of rectangular thin-plate weirs, J Hydraul. Div. ASCE 83, 1-36, 1957.

Lumbroso, D. M. and Vinet, F.: A comparison of the causes, effects and aftermaths of the coastal flooding of England in 1953 and France in 2010, Nat. Hazards Earth Syst. Sci., 11, 2321-2333, doi:10.5194/nhess-11-2321-2011, 2011.

Mason, D. C., Bates, P. D., and Dall' Amico, J. T.: Calibration of uncertain flood inundation models using remotely sensed water levels, J. Hydrol, 368(1-4), 224-236, doi:10.1016/j.jhydrol.2009.02.034, 2009.

Mazzanti, P. and Bozzano, F.: An equivalent fluid/equivalent medium approach for the numerical simulation of coastal 1 andslides propagation: theory and case studies, Nat. Hazards Earth Syst. Sci., 9, 1941-1952, doi:10.5194/nhess-9-1941-2009, 2009.

Morton, R. A. and Barras, J. A.: Hurricane Impacts on Coastal Wetlands: A Half-Century Record of Storm-Generated Features from Southern Louisiana, J. Coastal Res., 275, 27-43, doi:10.2112/JCOASTRES-D-10-00185.1, 2011.

Nicolle, A., Karpytchev, M., and Benoit, M.: Amplification of the storm surges in shallow waters of the Pertuis Charentais (Bay of Biscay, France), Ocean Dynam., 59, 921-935, doi:10.1007/s10236-009-0219-0, 2009.

Pawlowski, A.: Géographie historique des côtes Charentaises, Le Croix vif (Ed), Paris, 235 pp., 1998.

Peng, M., Xie, L., and Pietrafesa, L. J.: A numerical study on hurricane-induced storm surge and inundation in Charleston Harbor, South Carolina, J. Geophys. Res., 111, C08017, doi:10.1029/2004JC002755, 2006.

Perillo, G. M. E.: Chapter 2 Definitions and Geomorphologic Classifications of Estuaries, in Geomorphology and Sedimentology of Estuaries, 53, 17-47, Elsevier, http://www.sciencedirect.com/ science/article/pii/S0070457105800226, 1995.

Poirier, C., Chaumillon, E., and Arnaud, F.: Siltation of riverinfluenced coastal environments: Respective impact of late Holocene land use and high-frequency climate changes, Mar. Geol., 290, 51-62, doi:10.1016/j.margeo.2011.10.008, 2011.

Poulter, B. and Halpin, P. N.: Raster modelling of coastal flooding from sea-level rise, Int. J. of Geogr. Inf. Sci., 22, 167-182, doi:10.1080/13658810701371858, 2008.

Rego, J. L. and Li, C.: On the importance of the forward speed of hurricanes in storm surge forecasting: A numerical study, Geophys. Res. Lett., 36, L07609, doi:10.1029/2008GL036953, 2009.

Rego, J. L. and Li, C.: Storm surge propagation in Galveston Bay during Hurricane Ike, J. Mar. Syst., 82, 265-279, 
doi:10.1016/j.jmarsys.2010.06.001, 2010.

Schmith, T., Kaas, E., and Li, T. S.: Northeast Atlantic winter storminess 1875-1995 re-analysed, Clim. Dynam., 14, 529-536, 1998.

Schumann, G., Bates, P. D., Horritt, M. S., Matgen, P., and Pappenberger, F.: Progress in integration of remote sensingderived flood extent and stage data and hydraulic models, Rev. Geophys., 47, doi:10.1029/2008RG000274, http://www. agu.org/pubs/crossref/2009/2008RG000274.shtml, (last access: 6 November 2012), 2009.

Simon, B.: Statistiques des niveaux marins extrêmes de pleine mer en Manche et Atlantique, CD-Rom, edited by SHOM and CETMEF, 2008 (in French).

Smith, R. A. E., Bates, P. D., and Hayes, C.: Evaluation of a coastal flood inundation model using hard and soft data, Environ. Modell. Softw., doi:10.1016/j.envsoft.2011.11.008, available from: http://linkinghub.elsevier.com/retrieve/pii/S1364815211002635, (last access: 6 November 2012), 2011.

Tolman, H. L.: User manual and system documentation of WAVEWATCH-IIITM version 3.14, Technical note, MMAB Contribution, (276), 2009.

Wächter, J., Babeyko, A., Fleischer, J., Häner, R., Hammitzsch, M., Kloth, A., and Lendholt, M.: Development of tsunami early warning systems and future challenges, Nat. Hazards Earth Syst. Sci., 12, 1923-1935, doi:10.5194/nhess-12-1923-2012, 2012.
Webster, T. L.: Flood Risk Mapping Using LiDAR for Annapolis Royal, Nova Scotia, Canada, Remote Sens., 2, 2060-2082, doi:10.3390/rs2092060, 2010.

Webster, T. L., Forbes, D. L., MacKinnon, E., and Roberts, D.: Flood-risk mapping for storm-surge events and sea-level rise using lidar for southeast New Brunswick, Can. J. Remote Sens., 32, 194-211, 2006.

Wolf, J.: Coastal flooding: impacts of coupled wave-surge-tide models, Nat. Hazards, 49, 241-260, doi:10.1007/s11069-0089316-5, 2008.

Wolf, J. and Flather, R. A.: Modelling waves and surges during the 1953 storm, Phil. Trans. R. Soc. London Ser. A, 363, 1359-1375, doi:10.1098/rsta.2005.1572, 2005.

Young, A. P., Guza, R. T., O'Reilly, W. C., Flick, R. E., and Gutierrez, R.: Short-term retreat statistics of a slowly eroding coastal cliff, Nat. Hazards Earth Syst. Sci., 11, 205-217, doi:10.5194/nhess-11-205-2011, 2011.

Zhang, Y. and Baptista, A. M.: SELFE: A semi-implicit Eulerian-Lagrangian finite-element model for crossscale ocean circulation, Ocean Model., 21(3-4), 71-96, doi:10.1016/j.ocemod.2007.11.005, 2008. 